\title{
METHODS OF COMPENSATION
}

\section{Yousef Yaghoubi Mahmoudabadi ${ }^{1}$ Mansour Amini²}

\begin{abstract}
Compensating for a loss is among the most fundamental objectives of every legal system. There are various methods for compensation and they are placed into two sets of objective and cash payment compensation. In some of the legal systems such as Iran's there is an order observed between these two methods that means firstly the objective compensation is applied due to restitution to a prior situation and being closer to the just and fair procedures and in case of existent excuses cash payment is utilized. Because the objective method of compensation has shortcomings, it is no deemed as superior in our legal system and the legislator in the article 3 of the civil liabilities gives the judge the discretion to determine the method of compensation. England law puts its basis on cash or pecuniary payment and objective method is considered as an exception. The criterion time for compensation in Iran's law is the remittance time. In our legal system sentencing to pay compensation for a loss should be in advance and at once, other than exceptional cases such as physical damages where the judge has the option of reconsideration of the sentence up to two years since the date the verdict has been issued based on article 5 of civil liability Act. The situation is the same in England system and the axiom of once and for all is useful in the same issue and only in case a new cause appears a possibility for reclaiming compensation for a loss may arise.
\end{abstract}

Keywords: Objective Compensation, Pecuniary Payment, Recompensing The Exact Property, Remittance Time, Property Restitution

\section{Resumo}

Compensar uma perda está entre os objetivos mais fundamentais de todo sistema legal. Existem vários métodos para compensação e eles são colocados em dois conjuntos de objetivos e compensação de pagamento em dinheiro. Em alguns dos sistemas legais, como o do Irã, há

\footnotetext{
${ }^{1}$ PhD Student, Private Law, Department of Law, Theology and Political Science, Science and Research Branch, Islamic Azad University, Tehran, Iran. E-mail: yousef.yaghoubi2018@gmail.com

2 Associate Professor, Department of Law and Political Science, Science and Research Branch, Islamic Azad University, Tehran, Iran (Corresponding Author). E-mail: m-amini@srbiau.ac.ir
} 
uma ordem observada entre esses dois métodos que significa que a compensação objetiva é aplicada devido a restituição a uma situação anterior e estar mais perto dos procedimentos justos e justos e em caso de desculpas existentes. é utilizado. Como o método objetivo da compensação tem deficiências, não é considerado superior em nosso sistema jurídico e o legislador no artigo 3o do passivo civil concede ao juiz a discrição para determinar o método de compensação. A lei da Inglaterra baseia-se em dinheiro ou pagamento pecuniário e o método objetivo é considerado uma exceção. O tempo de critério para compensação na lei do Irã é o tempo de remessa. Em nosso sistema legal, a sentença para pagar uma indenização por uma perda deve ser antecipada e imediatamente, exceto casos excepcionais, como danos físicos, em que o juiz tem a opção de reconsiderar a sentença até dois anos após a data em que a sentença foi emitida. com base no artigo 5 da Lei de Responsabilidade Civil. A situação é a mesma no sistema da Inglaterra e o axioma de uma vez por todas é útil na mesma questão e somente no caso de uma nova causa aparecer uma possibilidade de recuperar a compensação por uma perda pode surgir.

Palavras-chave: Compensação Objetiva, Pagamento Pecuniário, Recompensa do Imóvel Exato, Tempo de Remessa, Restituição de Propriedade

\section{DAMAGE COMPENSATION QUALITY IN CIVIL LIABILITY}

The most important goals of the civil liability in most of the legal systems is recompensing for the loss, satisfying the inflicted party and restitution to a prior situation and deterrence. The main factor in determining the civil liability effects in all the legal systems is "compensating for a loss". The general rule is that anyone incurred the despicable and harmful act of the other can claim for compensation and the doer of the harm is obliged to reimburse. The question is raised as which of the following two cases would be the primary obligation of the doer of the harmful act: Should the imposed damage be removed of exactly the same part of the property which has been damaged or does it suffice to make it up for the deficit inflicted in the property, as a whole?

The topic of compensation in Iran's law has bases and roots which has been firstly put forth and developed in jurisprudence without gaining a recognition and understanding of which 
comprehending the compensation system in Iran's law seems improbable. Here, having a look at the jurisprudential background of the topic seems necessary.

\section{Compensation background in jurisprudence}

In Islamic jurisprudence, including Imammiyeh and general, there is no independent topic discussing compensation. According to the fact that some inflictions such as spiritual losses or lack of benefit have no clear stance in Islamic jurisprudence and in some authors' ${ }^{3}$ ideas there is a limited meaning accepted of the term 'loss' in Islamic law, there are prominent examples of objective, spurious compensation proposed in conventional and involuntary liabilities.

In Imammiyeh jurisprudence, objective compensation has been stated in some of the cases for instance in usurpation it is expressed that so long as the usurped property is existent the usurper is obliged to return it as it is albeit deficient and lacking or its return faces the usurper with difficulty and this is a general consensus reached by the Imammyieh scientists ${ }^{4}$. In the meantime, if the usurper has farmed the usurped land or planted a tree or constructed a building $\mathrm{s} /$ he is obliged to uproot and destroy the farm, trees and the building and besides destroying the plantation $s / h e$ is obliged to level the ground and filling in the holes ${ }^{5}$ and this is the very objective compensation. Therefore, Imammyieh jurisprudence has paid a special attention to restitution and objective compensation and considers it as being precedent to the spurious compensation. Also, in public jurisprudence there are cases of objective compensation which are predominantly similar to the cases extant in Imammiyeh jurisprudence. Regarding the necessity to return the exact property if it can be envisaged as possible there is a consensus between the public jurisprudence. Some jurisprudents mention other cases of objective compensation in Usurpation Book for specimen where an individual usurps a house and performs decorative and plaster works therein, if the owner requests removal of the decorative works and such a request has a reasonable goal the usurper is obliged to remove them and if the house is incurred with a deficiency s/he has to pay a price. Also, if the owner usurps another

\footnotetext{
${ }^{3}$ Al-Sanhuri, Abd Al-Razzaq, Ahmad, "Masader Al-Haq fi Al-Fiqh Al-Islami", two-volume, 6 ${ }^{\text {th }}$ part, $1^{\text {st }}$ ed., Beirut, Lebanon, Dar AL-Ahya' Al-Torath Al-Arabi, 1997, p.118

4 Najafi, Muhammad Hassan, Javaher Al-Kalam fi Sharh Sharaye'e Al-Islam", v.38, Islamic publication office of Qom, 2014, 16 ${ }^{\text {th }}$ ed., p.75

${ }^{5}$ Al-Tusi, Muhammad Ibn Hussein Ibn Ali (Sheikh Tusi), "Al-Mabsut fi Fiqh Al-Imammiyeh", v.3, Beirut, Lebanon, Dar Al-Kitab AL-Islami, no date, $8^{\text {th }}$ ed., p.75
} 
land and transfers its soil, if it is asked by the owner and such a request follows a reasonable goal the usurper is obliged to return the soil and spread it over the land as it was before. In jurisprudence, objective compensation is not the sole way of reimbursing damages and other methods, as well, are decreed as deemed expedient.

In Imammiyeh jurisprudence there are different types of spurious compensation such as the same property or its price in regard of the damages imposed on the properties and atonement for making up for the physical losses and injuries. In the first place, a sentence is issued to return the exact same thing in case that the wasted property is an fungible one, but if it is not money or the price is paid. In cases that there is a possibility to return the exact object it supersedes the price and this supersession means neither the doer of the harm nor the sufferer cannot ask for the payment of price ${ }^{6}$. In public jurisprudence, in case that a loss or wastage has happened in the properties, different types of spurious compensation including the exact example, or the price have been considered. Such an idea has been asserted regarding usurpation and in case that the usurped property has been wasted and secondly in discussions on wastage and causality ${ }^{7}$. In both of the cases if the wasted property is a fungible one the same specimen of the property should be paid and if it can be valued by a certain price, or if returning an example of the property is not possible, a price should be paid. Such a verdict is agreed upon by all of the public religions ${ }^{8}$.

\section{Objective compensation of damage (restitution)}

One of the common and significant ways of compensating for a loss in the law of different countries is the objective compensation which is sometimes termed as restitution to a previous condition of the inflicted ${ }^{9}$ or generic reparation ${ }^{10}$. Regarding the objective compensation it is said that the loss should be reimbursed in such a manner that it is as if there has not been originally such a loss. Therefore, this method of compensation is manifested in returning the exact property back or damage source removal. In cases that the factor behind the loss performs something which constantly causes losses, the removal of the loss source is

\footnotetext{
${ }^{6}$ Sheikh Tusi, Ibid, p.60, Najafi, Muhammad Hassan, Ibid, p.85

7 Al-Zajbali, Wahiyeh Ibn Mustafa, Al-Fiqh Al-Islami wa Adellatahu", 12 ${ }^{\text {th }}$ ed., no date, Dar Al-Fikr Suriya, Damascus, pp.483-6

${ }^{8}$ Al-Zajili, Wahiyeh Ibn Mustafa, Ibid, p.481

${ }^{9}$ Katuziyan, Naser, "compulsory obligation", civil liability, Tehran University, $5^{\text {th }}$ ed., 2007, p.526

${ }^{10}$ Hosseininejad, Husseingholi, "civil liability", MAjd, $4^{\text {th }}$ ed., 2010
} 
not the best method of compensating for a loss. This method of compensation is the best method and in the meantime one of the important objectives of civil and conventional liability. Some writers know objective compensation only in conventional liability, but such an important issue having a particular standpoint in civil liability should not be ignored. There are many law writers $^{11}$ who mention numerous instances regarding objective compensation in civil liability, for example the demolition of a building which has been built against the regulations, rendering a forged document invalid and publishing a sentence issued regarding a slanderer and so forth.

In such a method, it has not been sufficed to making up for the deficiency incurred in the property rather it is important that the part of the property which has been damaged should be repaired or restituted.

Based on this, at the first sight, it seems that the methods attempting to restitute are closer to fairness and for the same reason the legal regulations primarily give superiority to such methods ${ }^{12}$. So, it can be said that restitution is equivalent to performing the exact commitment in conventional obligations and equivalent pecuniary payments are identical to payments for not accomplishing an obligation and it is evident that performing the exact commitment is superior to paying for a spurious substitution of the obligation. England law, as well, pays attention to such a method of compensation both regarding conventional responsibilities and nonconventional responsibilities. As for the conventional liabilities, it is interpreted as performing the exact obligation or special execution ${ }^{13}$ of the commitment and in nonconventional liabilities it is termed returning the exact property ${ }^{14}$.

\section{The instances of objective compensation}

Such a type of compensation is viewed in two ways: the harmful action sometimes leads to a damage of a part of property and in fact this is the effect of the harmful action that is required to be eliminated; that is, the damaged property should be repaired in order for the inflicted conditions to be restored to a previous situation. The instances of such a case are many. Cases where the doer of the harmful action is sentenced to repair the resulted damaged or relieving the incurred deficiency as well as the cases that $s /$ he is sentenced to submit an

11 Atef Al-Nnaghib, "Al-Nazrit Al-Ammeh Lil-Mas'ouliyat Al-Nnashe'at An-Al-Fe'el Al-Shakhs", $3^{\text {rd }}$ ed., Beirut, Manshurat Avidat, 1984, p.385, Lurasa, Mitchel, Ibid, p.151

12 Article 329 of civil law, also; Katuziyan, Naser, Ibid, no.189

${ }^{13}$ Specific performance

${ }^{14}$ Specific restitution of property 
exact example of the wasted property are among such a set of compensation efforts. And, it is sometimes the harmful state that is required to be restored to a previous status.

Damaged property reparation

Article 329 of civil law Act ${ }^{15}$ is a specimen of restitution. According to the criterion of the aforesaid article, when a harmful act leads to a damage or a deficit in a property which can be repaired or restored the doer of the action has to repair the property and restore the property to a previous condition with doing so. By the necessity to repair the property it is not intended that the wrongdoer is himself responsible to repair the property on his own rather it suffices that the office take responsibility of such an operation although it is assigned to a third party. The issue here is the validation of article 329 if civil law according to article 3 of civil liability law enacted in 1960. Based on article 3 of the civil liability act "the court is responsible for determining the damage magnitude, compensation method and the way it has to be reimbursed according to the case-specific status and situation...." So, the judge is responsible for determining the compensation method and if he, hypothetically, in the examples of article 329 of civil law, recognizes that compensation via paying in cash is more appropriate than repairing the property and restoring it to its primitive form, the defendant will be sentenced to compensate the damage as deemed appropriate by him.

To solve such a problem, assisted by the law logic it is stated that "article 3 of public civil liability is subsequent because it is a principle which generally settles the way the compensation method should be determined in reparable damages imposed on a property and as it is publicly stated a certain subsequent cannot render a precedent obsolete rather a precedent specificity functions as a subsequent generality ${ }^{16}$.

Although due to not revoking the law and the summing of the two codes of $\operatorname{law}^{17}$ it has to be accepted that originally the subsequent generality does not render the precedent specificity obsolete but it is sometimes made clear via the evidences and clues that the legislator has sometimes been attentive to precedent specificities in order to enforce general

\footnotetext{
${ }^{15}$ Article 329 of civil law: "should anyone destroy a person's house or building s/he has to construct it exactly as it was before and if it is not possible s/he has to afford its price".

16 Katuziyan, Naser, "an introduction to the science of law", 1994, Enteshar enterprise co. with Bahman Borna's cooperation, 1997, 22 $2^{\text {nd }}$ ed., no.146

17 "Al-Jam'a mahoma Amkana men Al-Ttarh", R.K., Mohammadi, Abu Al-Hassan, "the principles of Islamic law inferences", Tehran publication institution, $57^{\text {th }}$ ed., 2016, no.117
} 
verdicts. ${ }^{18}$ Concerning our discussion, if it is made evident that the law changes have shifted towards the direction that compensation for a loss in the form of cash payments is preferred to the other methods, the options existent in article 3 of the civil liability law can be assumed as a tool by way of which the judge can engage the new changes in trial course. In other words, taking steps to enact article 3 along with such changes is reflective of the legislator's tendency towards retraction from article 329 of the civil law confinements regarding the compensation methods.

Giving a similar example of the damaged property

Based on articles $317^{19}, 328^{20}$ and $331^{21}$ of civil law another instance of sentencing to restitution is when the liable person is sentenced to pay a similar example of the damaged property. The necessity for paying a similar example of the damaged property is when the property is fungible but if it is non-fungible the liable person should pay the price ${ }^{22}$. In other words, if the property is among the goods the similarities and examples of which are abundant it is a fungible goods (Article 950 of civil law) and for compensation a similar example of the property should be returned and price payment (pecuniary equivalent) is when the commodity is not among the properties the similarities and examples of which are abundant or, in other words, the pecuniary equivalent payment is used when returning a similar example cannot be fulfilled. It is clear that returning an example restitutes the inflicted person's status to a previous condition and it substitutes a similar item to the same part of the damaged property and this is why it is more superior to payment of cash price.

Here a question is raised that whether article 3 of civil liability and the judge's discretion in selecting the compensation method cause an obsolescence of such a priority or not? And, the judge cannot for example in case that the situation makes it necessary issue a sentence for paying the price for a wasted property instead of sentencing the submission of a similar

\footnotetext{
${ }^{18}$ Katuziyan, Naser, ibid, no.146, p.184

${ }^{19}$ Article 317 of the civil law: "the owner can ask for the exact property and in case it is wasted the exact example and/or the price for the whole or part of the usurped property from the primary usurper or any of the later usurpers whom $\mathrm{s} /$ he wishes".

${ }^{20}$ Article 328 of civil law: "should anyone waste another person's property s/he is held liable for it and has to return a similar example or a price for it...".

${ }^{21}$ Article 331 of civil law: "if any person causes the wastage of another person's property s/he has to give back a similar example or a price for it."

22 Emami, Seyyed Hassan, "civil law", v.1, 1985, p.368, Katuziyan, Naser, "compulsory obligation-civil liability", no.194
} 
example? The only difference of the discussion lies in the idea that regarding the current debate the superiority of returning a similar example over paying the price has not been explicitly mentioned in the law and the legislator has made use of both these terms and the superiority has been mined out of the legal theories, despite the damaged property reparation which has been explicitly expressed by the legislator that the liable has to repair the property and restore it to its previous condition and so on, and if it is not possible the price payment must be afforded (article 329 of civil law). Therefore, if the judge, as a jurist, discovers that employing price payment better serves the inflicted person, s/he can benefit from the options implied by article 3 of the civil liability to determine the method of compensation and there is no legal inhibition in the form of a specific code of law ${ }^{23}$.

\section{Intervenient Exchange}

Legislator makes reference to intervenient exchange in article 311 of civil law. Intervenient exchange is in fact an exchange for a usurped property and for compensating the loss resulting from the distance created between the property and the owner ${ }^{24}$. Based on such a strategy, until returning the exact property is facilitated, a property similar to the usurped one or with the same usability is exchanged and made available to the owner in order for his or her status to be restored to a previous condition before usurpation to the maximum extent possible.

Property reparation, returning an exemplary property and intervenient exchange do not have a place in England law. The courts of this country realize cash payment as a principle in compensation in such a manner that fulfilling the exact obligation in the contracts' law is an exceptional and especial method ${ }^{25}$.

Harmful state removal

\footnotetext{
23 Katuziyan, Naser, "compulsory obligation-civil liability", no.189

24 Ibid, p.403, Emami, Seyyed Hassan, Ibid, p.403, Ja'afari Langerudi, Muhammad Ja'afar, "Law Terminology", 2009, no.825

25 The usual remedy for common law causes of action is damages. Damages are an amount of money that the defendant must pay to the plaintiff as compensation for the damage or injury caused by the defendant's conduct. Anita Stuhmcke, ESSENTIAL TORT LAW, p. 180. $2^{\text {nd }}$ ed., 2001, Sydney, London
} 
The common concept striking the mind of the term civil liability is recompensing the loss resulting from a harmful act. Civil liability is the individual's being obliged to make up for the damage incurred because of his actions and the obligations put by the custom or law on the individual's shoulder in order to defer him from performing actions or urge him to perform actions cannot be entered in the civil liability conceptualization circle. According to what was said, prevention from and removal of the harmful state can sometimes be a method of obviation of the loss and restoring to a previous condition and it is based on the civil liability basics: when the harmful act is a crime or an action which is legally forbidden such a state is not the case; because, the source of such actions is rooted in the legislator's direct verdict but if the harmful action is in fact implementation of a right of the doer of the action's rights there is no legal prohibition of such an action accomplishment. Now, if a theory of the civil liability theories holds the doer of the action liable, though he has been doing it in line with exertion of his own right, then deferring from performing the harmful action is a method of compensation. The harmful action in this state is deterred as a result of the obligations resulting from civil liability and there is no preliminary deterrence by the legislator in this regard. In theory of misusing one's own right, harmful action is a misconduct which is legally regarded as a right of the doer of the action, and no one can prevent an individual from exerting his own right but, as a sophisticated theory in civil liability the issue is raised that if a person, having malevolent intentions, exerts his own rights at the cost of harming the others and incur them with a loss by doing so, such a harm should be compensated. The theory of misusing one's own right does not confine a right rather it accepts the right as a just privilege and it implies the way a right should be executed and it expresses a person's liability who has applied his own right at the cost of harming the others. Therefore, the theory of misusing one's own right is a premise for civil liability.

In England law as well the deterrence and commitment stipulations are used to remove a harmful state. Deterrence stipulations are instructions which prevent the defendant from perpetrating an illegitimate civil action ${ }^{26}$ and commitment stipulations are orders which force the defendant to perform an action. Simultaneous claiming for such stipulations along with claiming for compensation is possible. If it is proved in England courts that a harmful behavior may continue they take actions to issue a deterrence stipulation ${ }^{27}$ unless there is a firm reason why such a stipulation should not be issued.

\footnotetext{
${ }^{26}$ tort

27 prohibitory injunctions
} 


\section{The shortcomings of this compensation method}

As it was mentioned, the methods attempting to repair the same part of the property which is damaged and restore it to a previous condition can better compensate for a loss. However, there are drawbacks in this method which justify the use of pecuniary equivalent in compensating for a loss. Also, if the objective compensation superiority is accepted the use of such a method is not possible in all of the cases. In such cases, the loss should be reimbursed with a sum of cash. Legislator has pointed this out in articles 317, 320 and 331 of the civil law but where the objective compensation methods are possible resorting to such a method is anyhow not free of faults. In this way, the defendant's obligation regarding this method of compensation is making him committed to perform an action that means the defendant should repair the property or procure a similar example of the damaged property. In terms of the defendant's coercion mechanism, his commitment here is the same as obliging an individual to perform a duty and if he falls short of performing it, he can only be charged with the cost of performing such a duty (articles $237 \& 238$ of civil law). This is in practice the pecuniary equivalent of the loss. Also, one should not forget that compensating for a loss aims at preserving the inflicted person's rights therefore his propensities in selecting the various methods should not be neglected ${ }^{28}$.

\section{Cash compensation}

In this method of compensation generally it is tried to restitute the property status of an inflicted person to a state before the happening of the harmful action ${ }^{29}$. The properties components are always changing and the idea whether a person has suffered a loss or benefited is assessed based on the whole assets. If the amount of the assets is increased the individual has benefited and if it is reduced the individual has suffered a loss. So, if a sum of money is paid to the inflicted after an incident has taken place in such a manner that the deficiency incurred on a property can be made up then it cannot be said that the losses have not been compensated for. Therefore, the compensatory potency of this method is not

\footnotetext{
${ }^{28}$ Lurasa, Mitchel, "civil liability", tr. Muhammad Ashtari, Hoghughdanan, $1^{\text {st }}$ ed., 1997, p.171

29 Hosseininejad, Hosseingholi, "civil liability", p.96, Faqih Nakhjiri, Hassan, "private claims in criminal courts", p.231
} 
dubious. The only problem is that which one of the two methods, objective compensation or cash equivalent payment, is superior over the other. It was mentioned that the basis of the objective compensation methods superiority over cash equivalent payment lies in the foundation that in objective compensation it is exactly the same damaged part of the property that is repaired and, in this regard, it is better than cash equivalent which only suffices to removing the incurred deficit in the property. But, it has to be said that such an advantage does not have a robust role in compensation concept. Originally, the harm imposed on an individual who has received a sum of money identical in value to the amount of the loss incurred has been compensated. Such an issue plus the drawbacks mentioned regarding the objective compensation method makes us not to consider the objective compensation as being superior to the cash equivalent payment. Such a conclusion complies with the legislation trend. Article 3 of civil liability allows the judge to select his own appropriate method of compensation.

\section{DAMAGE ASSESSMENT METHODS}

Corresponding to article 3 of civil law, originally, damage and its pecuniary equivalent evaluation is at the judge's discretion. In this way, the judge determines what losses have been incurred of a harmful action, the doer of the action should be held liable for the compensation of which harms and how much cash equivalent should be attributed thereto ${ }^{30}$. Also, legislator sometimes assists the judge and determines the original damage case-specific that is the same harm which has resulted from a harmful action. For example, in wasted properties cases the main damage is the price of the wasted property (articles 317, 328 and 331 of civil law) or if the profit of a property is wasted the main damage that should be compensated is the similar price of the profit (article 488 of civil law). Therefore, it is possible for the legislator to determine a legal rate for the damage. Such an issue which is seen in conventional liability regarding the remittance delay losses can also be seen in compulsory obligation in atonement. Besides the damages for which the legislator has determined a rate, in the majority of the cases there is talk of what should be made up for the inflicted loser and what is the goal in civil liability of compensation? There is no special legal provision in this regard in Iran's law. But the idea has been fully dealt with in England law. In England law, a distinction has been made in the evaluation of the losses sustained as a result of conventional and nonconventional damages.

\footnotetext{
30 Faghih Nakhjiri, Hassan, "private claims in criminal courts", unknown publication place and number, 1972, p.234
} 
Regarding conventional losses, it has been said that the objective is putting the obligee in a situation $\mathrm{s} /$ he is supposed to be in case that the contract was implemented while the objective in nonconventional responsibility is placing the inflicted person in a situation where $s /$ he was supposed to be in case that no harm was imposed.

\section{Temporal factor in calculating the damage}

Regarding damage calculation, an interesting issue is the way the time factor is involved in damage calculation. Legal incidents do not happen in an imaginary and virtual environment rather they take place in real world one dimension of which is time. Unit titles such as price or equivalent price take different meanings with the pass of time and in determining the damage rate one should consider which one has to be used. The distinct instance of the issue can be shown in usurped property wastage. Anyhow, it should be noted that the losses imposed on the victim of a loss, for which the doer of the harmful action is liable, should be compensated. In line with this, the time factor can intensify or even mitigate the damage. Therefore, compensation should be in a way that no harm is left uncompensated for taking such a factor into consideration. To reach to such an objective it is possible that various methods may look correct and credible. In Iran's legal system the remittance time is the criterion and premise of compensation for a loss.

\section{Various methods of paying for a loss}

The courts' verdicts should be incontrovertible and a sentence cannot be issued with changeability. This is known as the judge's separation principle based on which the courts cannot change a sentence after it is issued. On the other hand, issuing a verdict of compensation is continuously against this principle. However, such principles involve an exception in respect to compensation, because in compensation the objective is restoring the inflicted to a previous condition and all of the incurred losses cannot be always recognized at once at the date the sentence is issued and it may be made clear in the course of time that the damage has been more than what has been predicted by the judge. In article 5 of civil law, legislator has pointed out such an issue and has let the judge to reconsider the sentence issued for two years since the date a verdict has been issued. Also, it is worth mentioning that a judge can consider compensation in a continuous manner through summing the legal conditions as 
mentioned in article 3 of civil law. For example, a case where the law allows a judge to continuously issue sentences corresponds to article 5 of civil liability regarding the damages imposed on body and health. In such a case, considering the status, if the judge realizes it as necessary, he can order a continuous form of compensation. The statuses which can encourage the court to do so involve issues such as the high rate of the damage and the defendant's inability to pay the compensation fees. There is a rule in England law termed "once and for all". Based on such an axiom, the entire damages resulting from the incidents and the instruments of a single lawsuit should be proposed at once and in a single trial course. Such a rule forces the plaintiff to claim for all the losses s/he has been incurred up to that point and the prospective damages at once ${ }^{31}$. It is possible that such an axiom along with the elapse of time signify the idea that the inflicted party cannot prove the losses which take place in future and it exactly holds true ${ }^{32}$.

\section{CONCLUSION}

There are variegated methods in legal systems for compensation. The most substantial of these is the objective compensation and cash payments. There is an order between these two methods in some systems such as our legal system in such a manner that cash payment is possible when objective compensation is impossible. In England legal system the general principle is paying cash equivalents and objective compensation is envisaged as an exception. Although objective compensation is closer to the justice in some cases because it is the same part of damaged asset which is repaired but this method has shortcomings including that it is impossible to resort to it in some cases. Another issue is that objective compensation is an obligation that should be shouldered by the defendant and if $s$ /he refrains from performing it there would be no other choice than requiring him or her to pay the equivalent which is the very topic of cash payment. Based on this, in legislative changes, the legislator in article 3 of the civil law allows the judge to select the way and the quality with which the compensation should be executed. Therefore, the judge can sentence the cash payment if he comes to the conclusion that it would better serve the inflicted than the objective compensation. In England law, there is

\footnotetext{
${ }^{31}$ Fournier v. Canadian National Railway Co. [1927] A.C. 167 at 16

32 David Wright, DISCRETION WITH COMMON LAW REMEDIES, (2002), Adelaide Law Review, no 23, pp. 243-275.
} 
a distinction between conventional and nonconventional damages. Regarding the conventional damages, it is said that it aims at placing the obligee in a situation where he was supposed to be in case that the contract was run whereas unconventional liability aims at placing the inflicted in a situation where he was supposed to be if no harm was sustained. Unlike the England law, in Iran's legal system there is no special text in this regard. Regarding the time during which the damage should be compensated it has to be mentioned that in Iran's legal system remittance time is the criterion and the basis of a verdict. In our legal system, the incurred loss should be considered in the sentence issued by the court all at once and after a verdict is issued the compensation cannot be sentenced again unless it is an exceptional case where the court, corresponding to article 5 of civil liability, regarding physical injuries, can revise its verdict up to two years since the date a sentence has been issued or it can sentence a continuous compensation. In England, as well, the situation is the same and it is termed "once and for all" and trying the damage after a verdict is issued is possible when there is a new cause to the lawsuit. 


\section{BIBLIOGRAPHY}

\section{Persian}

Elyas Now'ee, Ghasem Razavi, "article on the causality relationship in liabilities resulting from negligence; a comparative look at the Iran and England civil liabilities", seasonal journal of private law, no.15, Summer 2016, Allameh Tabataba'ee University

Emami, Seyyed Hassan, "civil law", v.1, 1985, p.368

Ja’afari Langerudi, Muhammad Ja'afar, "law terminology", 2009, no.825

Hosseininejad, Hosseingholi, "civil liability", Majd, 4th ed., 2010, p.96

Al-Zajbali, Vahba Ben Mustafa, "Al-Fiqh Al-Islami va Adellatahu", 12th ed., Dar Al-Fikr, Syria, Damascus, pp.483-6

Al-Sanhuri, Abd Al-Razzagh Ahmad, "Masader Al-Haq fi Al-Fiqh Al-Islami", two-volume, part six, 1st ed., Beirut, Lebanon, Dar Al-Ehiya' Al-Ttorath Al-Arabi, 1997, p.118

Al_tusi, Muhammad Ibn Ali (Sheikh Tusi), Al-Mabsut fi Figh Al-Emamiyeh, v.3, Beirut, Lebanon, Dar Al-Kitab Al-Islami, no date, 8th ed., p.73

Atef Al-Nnaghib, "Al-Nnazrit Al-Ammeh Lil-Mas'ouliyat Al-Nnashe'at An-Al-Fe'el Al-Shakhs", 3rd ed., Beirut, Manshurat Avidat, 1984, p.385

Faqih Nakhjiri, Hassan, "private claims in criminal courts", unknown publication place and number, 1972, p.231

\section{Iran's civil law}

Katuziyan, Naser, "compulsory obligation", civil liability, Tehran University, 5th ed., 2007, p.194 
Katuziyan, Naser, "an introduction to the science of law", 1994, Enteshar enterprise co. with Bahman Borna's cooperation, 1997, 22nd ed., no.146

Lurasa, Mitchel, "civil liability", tr. Muhammad Ashtari, Hoghughdanan, 1st ed., 1997, p.151

Mohammadi, Abu Al-Hassan, "the principles of Islamic law inferences", Tehran publication institution, 57th ed., 2016, no.117

Najafi, Muhammad Hassan, Javaher Al-Kalam fi Sharh Sharaye'e Al-Islam", v.38, Islamic publication office of Qom, 2014, 16th ed., p.75

\section{English}

David Wright, DISCRETION WITH COMMON LAW REMEDIES, (2002), Adelaide Law Review, no 23, pp. 243-275.

Fournier v. Canadian National Railway Co. [1927] A.C. 167 at 16

Trabalho enviado em 17 de abril de 2018

Aceito em 24 de maio de 2018 